\title{
Prenatal diagnosis of fetal acrania using two and three dimensional ultrasound
}

\author{
Yetkin Karasu, ${ }^{1}$ Murat Bozkurt, ${ }^{1}$ Servet Gençdal, ${ }^{1}$ Gülşah Tanas, ${ }^{1}$ Suat Dede,${ }^{1}$ Ayşe \\ Ender Yumru, ${ }^{2}$ Duygu Kara Bozkurt, ${ }^{3}$ Levent Sahin ${ }^{1}$
}

Keywords: Acrania, brain, cranium, 2D and 3D ultrasonography, prenatal diagnosis

\begin{abstract}
Malformations of the central nervous system are one of the most common congenital anomalies of the fetus. In this report we aimed to summarize a case of fetal acrania diagnosed in the first trimester and the use of two and threedimensional ultrasound in early diagnosis of the disease.
\end{abstract}

${ }^{1}$ Department of Obstetrics and Gynecology, Kafkas University School of Medicine, Kars, Turkey

${ }^{2}$ Şişli Hamidiye Etfal Education and Research Hospital, Department of Obstetrics and Gynecology, Istanbul, Turkey

${ }^{3}$ Department of Radiology, Kafkas University School of Medicine, Kars, Turkey

\section{Introduction}

Central nervous system (CNS) malformations are the second most frequent category of congenital anomalies, after congenital heart diseases. Most of the time ultrasound (US) examination is effective for the detection of these anomalies even in the first trimester of the pregnancy. Exencephaly or acrania is the absence of the entire or a major part of the fetal calvarium. Brain tissue is present but is not protected by a bony sheet. Sonographic assessment of the fetal skull contour in the first trimester in axial and sagittal planes and measurement of the bi-parietal diameter almost always ensure early diagnosis of exencephaly. With the progression in fetal imaging technology three-dimensional (3D) US has become an important tool for fetal

Please cite this paper as: Karasu Y, Bozkurt M, Gençdal S, Tanas G, Dede S, Yumru AE, Kara Bozkurt D, Şahin L. Prenatal diagnosis of fetal acrania using two and three dimensional ultrasound. Proceedings in Obstetrics and Gynecology, 2015;5(1):Article 4 [ 6 p.]. Available from: http://ir.uiowa.edu/pog/ Free full text article.

Corresponding author: Murat Bozkurt, Assistant Professor, Kafkas Üniversity Kampüsü Sağlık Araştırma ve Uygulama Hastanesi. Bülbül Mahallesi. Kombine Yolu Üzeri 3600 Kars/TURKEY. Tel: 905322279072, 905056330044. Fax: 047422514 30. E-Mail: jindrmb@yahoo.com

Financial Disclosure: The authors report no conflict of interest.

Received: 2 October 2014; received in revised form: 25 March 2015; accepted 30 March 2015; POG in Press, 30 March 2015

Copyright: (c) 2015 Karasu et al. This is an open-access article distributed under the terms of the Creative Commons Attribution License, which permits unrestricted use, distribution, and reproduction in any medium, provided the original author and source are credited. 
assessment. After the introduction of 3D US for fetal imaging additional benefits for the diagnosis of congenital CNS anomalies has been shown in many studies. $^{1,2}$

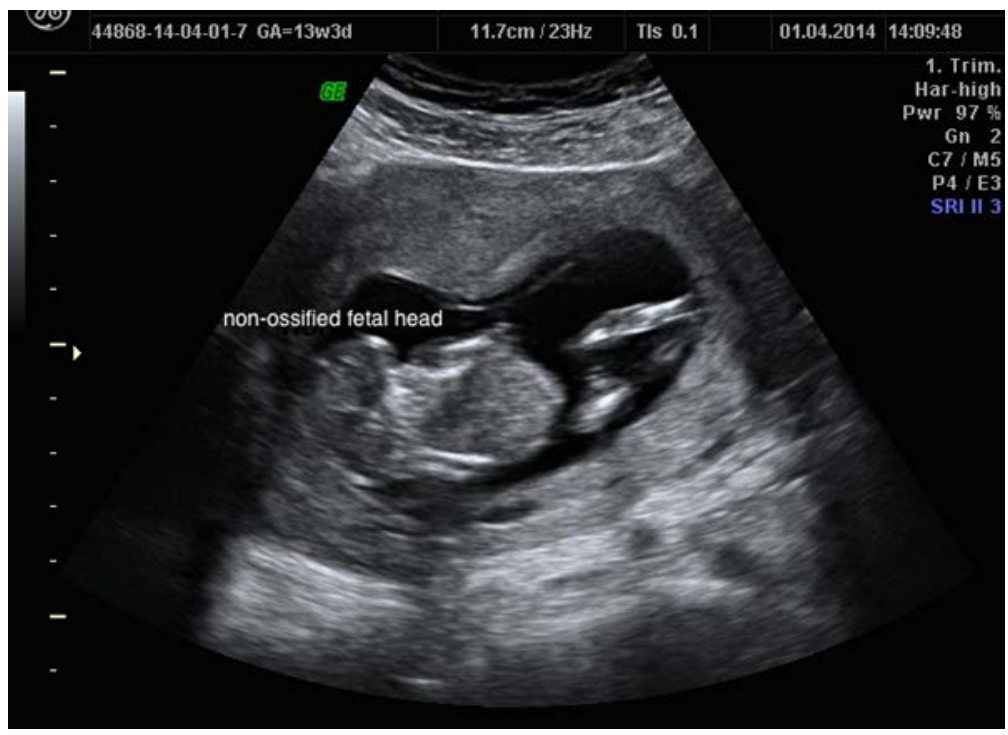

Figure I. Irregular, non-ossified fetal head

\section{Case Report}

A 20 year old primigravid woman was referred to our clinic at the 11th gestational week of pregnancy for first trimester screening. Medical anamnesis was uneventful. She was taking 400$\mu \mathrm{g} /$ day folic acid regularly. Twodimensional (2D) US (Voluson 730 Pro, GE Healthcare, Milwaukee, WI) exam revealed a live, singleton fetus at the 11th gestational week. The fetal calvarium was irregular in shape. There was no ossified bony structure at the upper part of fetal head and brain tissue was exposed to amniotic fluid and floating in it (Figure I). Cerebral hemispheres were present and falx cerebri was visible (Figure II). Threedimensional US revealed an abnormal cranium. The fetal brain was present but it was not protected by bony structures; the outer shape of the head is bi-lobed. The fetal face was irregular and fetal eyes were prominent. The nasal bone was present. There were no other malformations noted on US examination. Fetal magnetic resonance imaging was not diagnostic.

The family was informed about the condition and the pregnancy was terminated with medically induced abortion (misoprostol). Gross examination of the fetus confirmed the diagnosis of exencephaly (Figure IV). There were no other major anomalies. Pathologic examination showed a lack of bony structures at the upper part of fetal head and brain tissue was covered with a thin layer of endothelium. 


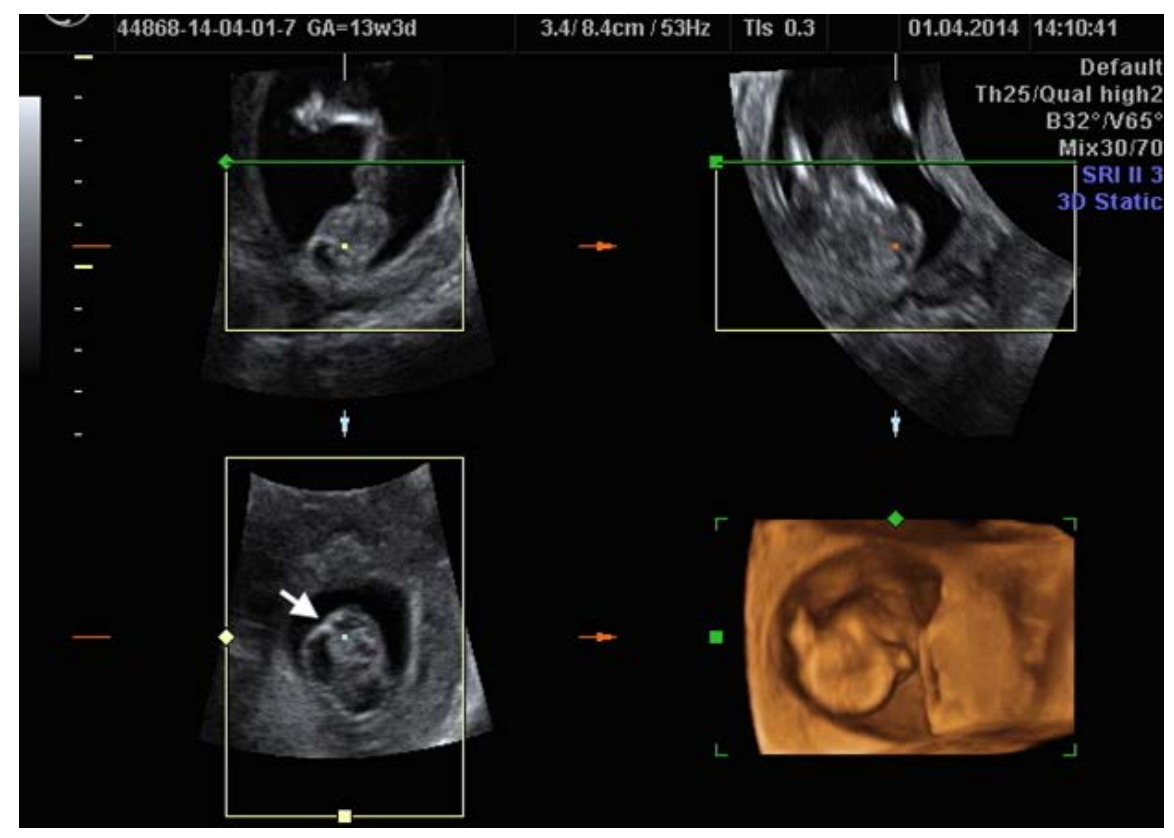

Figure II. White arrow: Falx cerebri

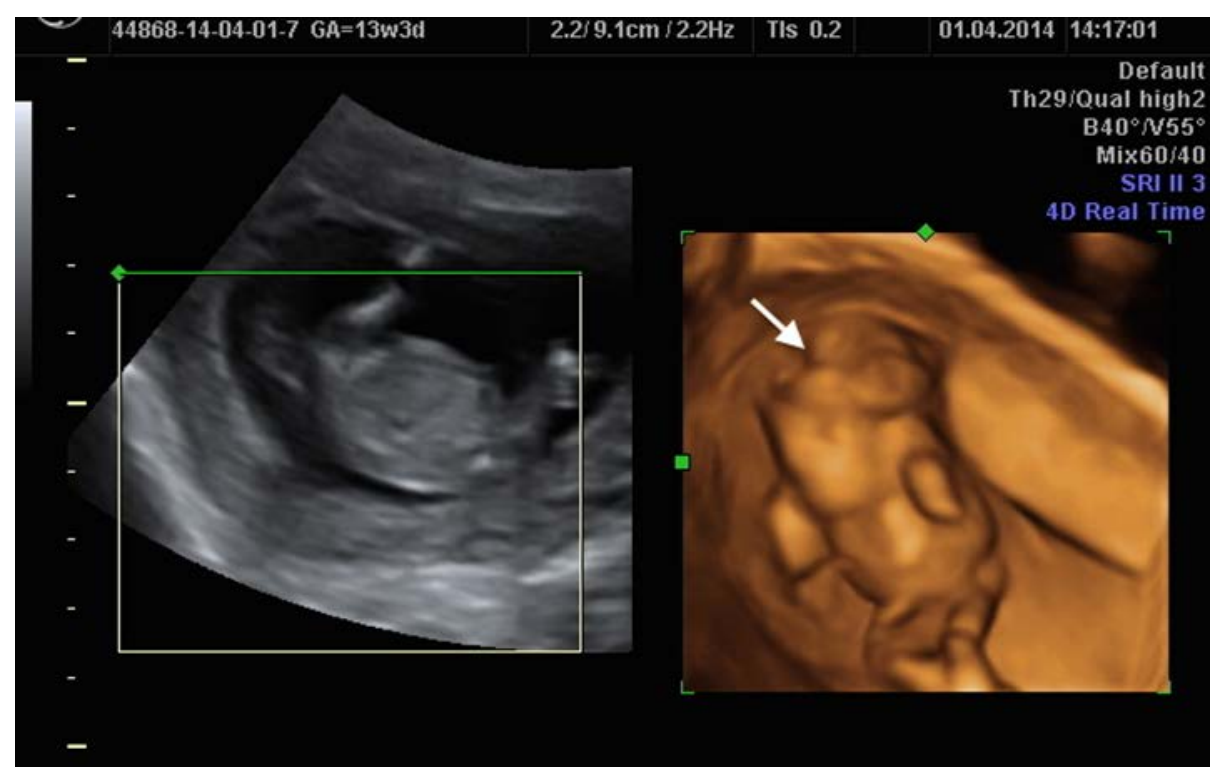

Figure III. White arrow: Abnormal fetal head on 3D US 


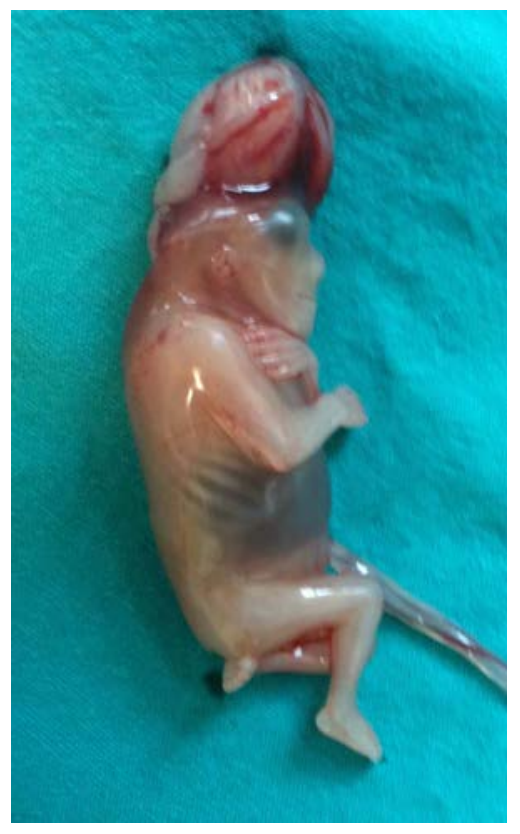

Figure IV. Absence of the upper part of the bony head

\section{Discussion}

Central nervous system anomalies are the second most common fetal anomalies, after cardiac anomalies $(1 / 100)$. Anomalies of the neural tube are multifactorial in origin. Chemicals, maternal status (DM), environmental factors (obesity, hyperthermia), therapeutic agents (valproate), deficiency of nutrients (folate), genetic syndromes (Meckel Gruber, trisomy 13) may increase the incidence of neural tube defects. ${ }^{3} \quad$ Exencephaly refers to the absence of the entire or a significant portion of the calvarial bones, but brain tissue is present. It is a rare anomaly resulting from failure of the mesenchyme to migrate under the ectoderm overlying the brain tissue to form the bony tissue over the cerebral hemispheres. ${ }^{4}$ The risk of recurrence for neural tube defects (NTD) is approximately $2-4 \%$ with one affected sibling. With two affected siblings, the risk is approximately $10 \%{ }^{5}$

The cerebral hemispheres are anatomically disorganized. Acrania is the most common CNS anomaly detectable in the first trimester. $^{6}$ Exencephaly usually progresses to anencephaly in the followings weeks of gestation. It must be kept in mind that the calvarial bones are not fully calcified before 10-11 weeks; therefore, first trimester diagnosis must be made with caution. ${ }^{7}$ Ultrasound is the main tool for diagnosis. Classical findings in $2 \mathrm{D}$ US exam are:

1. Lack of cranial bones or calcification at the upper part of fetal head

2. The surface of the cranial pole appears abnormal

3. Deformed and dorsally bulging abnormal head.

With the improvement in fetal imaging technology 3D-US became an important tool for the assessment of fetal anatomy. Additional gain of 3D-US to detect fetal CNS anomalies has been reported in the literature ${ }^{2,8}$ Threedimensional ultrasound has facilitated accurate and objective diagnoses of cranium bifidum/spina bifida, holoprosencephaly and associated anomalies in the first trimester and may allow detection of pathologic central nervous system (CNS) development at an earlier gestational age. ${ }^{9}$ It is important to examine fetal head development in all planes since it will be skipped in sagittal plane. Three- 
Proceedings in Obstetrics and Gynecology, 2015;5(1):4

dimensional US shows prominent interhemispheric cerebral fissure and dorsally bulging brain (Mickey Mouse Head) (Figure III). 5,10,11

Three-dimensional US allows analysis of images off-line as well as measuring diameters and volumes that may increase diagnostic accuracy. ${ }^{12}$ The ability to assess volumetric structure of the brain or other parts of the fetal head gives us new clues about diseases and the opportunity of designating characteristics of congenital malformations. Surface and volume rendered images provided by 3D-US help to present the exact level of problem. Also images obtained with 3DUS make it easier to understand the extent of the disease for both the physicians and the patients. ${ }^{13}$ The ability to rotate images is also useful in the evaluation of some of the CNS anomalies. ${ }^{1}$ New technologies such as HDlive image rendering may be very useful for the determination of structural anomalies of the developing fetus. ${ }^{13,14}$

\section{Conclusion}

Acrania is a severe and lethal malformation of the CNS that can be detected in the first trimester. Threedimensional US may help to clarify the extent and severity of the disease both for physicians and patients.

This study was presented at the 12th National Obstetrics and Gynecology Congress, 15-19 May 2014, Antalya, TURKEY

\section{References}

1. Dyson RL, Pretorius DH, Budorick NE, Johnson DD, Sklansky MS, Cantrell CJ, Lai S, Nelson TR. Three-dimensional ultrasound in the evaluation of fetal anomalies. Ultrasound Obstet Gynecol. 2000 Sep;16(4):321-8. http://dx.doi.org/10.1046/j.14690705.2000.00183.x. PubMed PMID: 11169307.

2. Liu IF, Chang $\mathrm{CH}, \mathrm{Yu} \mathrm{CH}$, Cheng $\mathrm{YC}$, Chang FM. Prenatal diagnosis of fetal acrania using three-dimensional ultrasound. Ultrasound Med Biol. 2005 Feb;31(2):175-8. http://dx.doi.org/10.1016/j.ultrasmedbio. 2004.10.005. PubMed PMID: 15708455.

3. Padmanabhan R. Etiology, pathogenesis and prevention of neural tube defects. Congenit Anom (Kyoto). 2006 Jun;46(2):55-67. PubMed PMID: 16732763.

4. Weissman A, Diukman R, Auslender R. Fetal acrania: five new cases and review of the literature. $\mathrm{J}$ Clin Ultrasound. 1997 Nov-Dec;25(9):511-4. PubMed PMID: 9350573.

5. Nussbaum, R, Mclnnes, et al. Genetics of disorders with complex inheritance. In: Thompson \& Thompson Genetics in Medicine, 6th, WB Saunders Co, Philadelphia 2001. p.289.

6. Pooh RK. Neurosonoembryology by three-dimensional ultrasound. Semin Fetal Neonatal Med. 2012 Oct;17(5):261-8. doi: 10.1016/j.siny.2012.05.008. Epub 2012 Jul 15. PubMed PMID: 22800609.

7. Chen CP, Chang TY, Lin YH, Wang W. Prenatal sonographic diagnosis of acrania associated with amniotic bands. J Clin Ultrasound. 2004 Jun;32(5):25660. http://dx.doi.org/10.1002/jcu.20021. PubMed PMID: 15124194. 
8. Gonçalves LF, Lee W, Espinoza J, Romero R. Three- and 4-dimensional ultrasound in obstetric practice: does it help? J Ultrasound Med. 2005 Dec;24(12):1599-624. PubMed PMID: 16301717.

9. Nishi T, Nakano R. First-trimester diagnosis of exencephaly by transvaginal ultrasonography. J Ultrasound Med. 1994 Feb;13(2):14951. PubMed PMID: 7932961.

10. Chatzipapas IK, Whitlow BJ, Economides DL. The 'Mickey Mouse' sign and the diagnosis of anencephaly in early pregnancy. Ultrasound Obstet Gynecol. $1999 \quad$ Mar;13(3):196-9. http://dx.doi.org/10.1046/j.1469-

0705.1999.13030196.x. PubMed PMID: 10204212.

11. Hata T, Uketa E, Tenkumo C, Hanaoka $\mathrm{U}$, Kanenishi K, Tanaka $\mathrm{H}$. Three- and four-dimensional HDlive rendering image of fetal acrania/exencephaly in early pregnancy. J Med Ultrasonics 2013;40(3):271-273.

http://dx.doi.org/10.1007/s10396-012-

0420-5

12. Blaas HG, Eik-Nes SH. Sonoembryology and early prenatal diagnosis of neural anomalies. Prenat Diagn. 2009 Apr;29(4):312-25. doi: 10.1002/pd.2170. PubMed PMID: 19194866.

13. Cajusay-Velasco S, Hata T. HDlive in the Assessment of Fetal Intracranial, Intrathoracic and Intra-abdominal Anomalies. Donald School J Ultrasound Obstet Gynecol 2014;8(4):362-375. http://dx.doi.org/10.5005/jp-journals10009-1376.
14. Hata T, Hanaoka U, Tenkumo C, Sato $\mathrm{M}$, Tanaka $\mathrm{H}$, Ishimura $\mathrm{M}$. Three- and four-dimensional HDlive rendering images of normal and abnormal fetuses: pictorial essay. Arch Gynecol Obstet. 2012 Dec;286(6):1431-5. doi:10.1007/s00404-012-2505-1. Epub 2012 Aug 7. PubMed PMID: 22868950. 